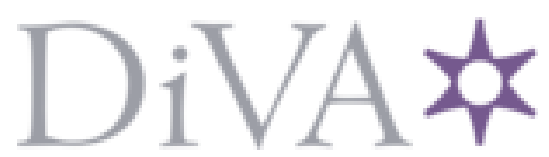

http://www.diva-portal.org

\title{
Postprint
}

This is the accepted version of a paper published in Museum History Journal. This paper has been peerreviewed but does not include the final publisher proof-corrections or journal pagination.

Citation for the original published paper (version of record):

Widén, P. (2015)

Meritorious Citizens in Royal Surroundings: The National Portrait Gallery of Sweden and its Use of a Historical Environment as Exhibition Space.

Museum History Journal, 8(1): 73-87

http://dx.doi.org/10.1179/1936981614Z.00000000041

Access to the published version may require subscription.

N.B. When citing this work, cite the original published paper.

Permanent link to this version:

http://urn.kb.se/resolve?urn=urn:nbn:se:uu:diva-244530 


\title{
Meritorious Citizens in Royal Surroundings: The National Portrait Gallery of Sweden and its Use of a Historical Environment as Exhibition Space
}

\begin{abstract}
:
The National Portrait gallery of Sweden was created during the 1820s. Its location in a sixteenth century royal palace outside of Stockholm makes it an interesting example of curatorial practices and experiments from a period before the scientification and specialization of museums in the 1850s and onwards. The portrait gallery built on the traditional royal picture galleries, but with the addition of commoners who were considered 'merited citizens' worthy to be included in a context of nationalistic pride. The narrative of the gallery was told not only by the portraits, but was also making use of the historical palace interiors and of guide book text that tried to create a mood in the visitor with the help of romanticized anecdotes, poetry, and quotes from plays, novels, and operas. The article focuses upon the curatiorial practices, the relation to other contemporary museums, and other possible sources of inspiration.
\end{abstract}

Keywords: National Portrait Gallery, museum history, curating history, Gripsholm Palace, Adolf Ludvig Stierneld

In the early 1820s the National Portrait Gallery of Sweden opened its gates to the public. The portraits that lined the walls of several rooms in the sixteenth century fortified castle of Gripsholm (Figure 1), some $70 \mathrm{~km}$ from Stockholm, were members of the royal family and their relatives, but with one very important addition — those regarded by the curator as 'merited Swedish citizens'. The palace had already in the early nineteenth century a long tradition of being a tourist attraction, and had been well-known for its collection of portraits during the eighteenth century. The first guidebook of the palace was published in 1754 and was followed by new guides by different authors in 1790, 1819, 1825, 1826, 1830, and 1833. The National Portrait Gallery, founded on the old tradition of royal picture galleries, intended to legitimize the throne's inhabitants by presenting portraits of royal relatives. What was new about the gallery, though, was that it also included commoners who were deemed 'merited' enough to be included in a statement of nationalistic pride. The location inside a royal palace also influenced the gallery's narrative, as the paintings were 
included in the royal apartments rather than being detached from the royal living space. This use of the historical environment as exhibition space, the use of inventive curatorial practices, together with the inclusion of commoners among traditional royal portraits, makes the National Portrait Gallery at Gripsholm Palace an important example of early nineteenth-century museology, before the 'scientification' of European museums in the 1850s and onwards. The article will focus mainly upon how the narrative was presented to visitors by analysing the curatorial practices used in the museum.

The creation of the National Portrait Gallery began during the years 1819-1823. The idea seems to have been initiated by the Marshal of the Realm, Count Claes Fleming (1771-1831), and the County Governor and Governor of Gripsholm Castle, Baron Pehr Skjo ldebrand (1769-1826), who discussed the matter in a letter in 1821. ${ }^{1}$ From this document it is clear that King Charles XIV (1763-1844) was informed of and approved the plans. The real creator and the first curator of the gallery, though, was the courtier, politician, collector, and historical documents forger, Baron Adolf Ludvig Stjerneld (1755-1835), former Chief Chamberlain of the Queen Dowager Sofia Magdalena (1746-1813). ${ }^{2}$ From c. 1820 until his death in 1835, Stjerneld (Figure 2) worked tirelessly on the gallery. He collected paintings and other objects deemed interesting, curated the exhibitions, and wrote several guidebooks to the museum. All his work was conducted in an informal fashion. There are no known appointments or records of decisions made regarding the museum and, apart from the transportation of some of the paintings (over the ice in winter time), no receipts have been found that tell us who paid for the arrangements. ${ }^{3}$ The transportation costs were taken from the general budget of the palace, but who paid for the paintings is unclear. Many of them were bought by Stjerneld personally, who then donated them to the gallery; others it seems were bought with the ordinary palace funds. ${ }^{4}$ It is likely, though, that the king personally paid for most of the expenses, but no evidence of this is in the archives. The sources of the early history of the gallery are therefore sparse and disparate and consist mainly of guidebooks written by the curator Stjerneld, a set of preparatory drawings for a never-realized print work (see Figure 3), and of letters between interested parties. In the guidebooks the exhibitions can be partly reconstructed, at least to the point of what

\footnotetext{
${ }^{1}$ Letter from P. E. Skjöldebrand to C. Fleming, April 23 1821, Uppsala universitetsbibliotek, F 818 f, 374.

${ }^{2}$ On the biography of Stjerneld, see Per Widén, 'Adolf Ludvig Stierneld,' Svenskt biografiskt lexikon, 33 (Stockholm 2011 ).

${ }^{3}$ The transportation receipts are kept in the Royal Palace Archive (Slottsarkivet).

${ }^{4}$ Many of the portraits in the gallery have painted inscriptions a tergo telling us the name of the donor, see e.g. U. G. Johnsson, 'Adolf Ludvig Stjerneld. Två porträtt,', in Porträtt porträtt. Studier i Statens porträttsamling på Gripsholm, ed. by U. G. Johnsson, (Stockholm: Rabén \& Sjögren, 1987), p. 89. There are also receipts preserved where Stjerneld states his donations to the gallery, e.g. a donation of two portraits of the colonels and counts Eric Brahe and Johan Ludvig Hårdh af Segerstad to the gallery 3 of August 1821. Slottsarkivet, Gripsholms slott, F 1:14.
} 
paintings hung on which wall, but the guidebooks offer significant insights into how the gallery and palace were intended to be perceived and what narrative the museum wanted to tell.

\section{A National Portrait Gallery}

The portraits of 'merited citizens' were mostly hung in a space between the Hall of State and a drawing room - known as the Hall of the Privy Council Members - outside the audience chamber on the piano nobile of the palace (Figure 3). The evidence suggests the exhibition in the gallery was somewhat disorganized, cluttered, and hung in no specific order, much to the curator's dissatisfaction. In the 1830 guide Handbok för resande till Griphsholms slott, the five-page list of names of people depicted ends with a footnote explaining that:

Of these 133 portraits only eight were here in 1823, and they were scattered around the Palace.

Because of the different sizes and the difficulties to make room for the large amount, one has been compelled to place them as one has been able to. The hanging is therefore not as to the benefit of the spectators, as one had wished. ${ }^{5}$

The selection of persons to be immortalized in the gallery as 'merited citizens' or 'extraordinary Swedes' was partly made according to the availability of pictures. Since the budget was minimal, and the gallery was made up of original portraits, the choice was limited. Stjerneld had, in his work as a curator, to trust his network and the patriotic feelings of the owners of old portraits. Apparently he did this rather extensively by more or less stealing desirable portraits from the walls of his friends and acquaintances. ${ }^{6}$

The selection of individuals in the gallery was not as haphazard as it might seem at first. In a series of advertisements in the state newspaper Post och Inrikes Tidningar between 1826 and 1829, Stjerneld published a short declaration about the purpose of the gallery together with an appeal to 'citizens' who might want to help increase the collection. The appeal was then followed by a list of desired portraits. The existence of this list shows that there was indeed a plan for the gallery and the list, together with the guidebook, offers evidence with which to analyse the idea and narrative of the museum.

\footnotetext{
${ }^{5}$ Adolf Ludvig Stjerneld, Handbok för resande till Gripsholms slott (Stockholm 1830), pp. 26-31. Original quote being: 'Af dessa 133 porträtter funnos endast åtta här år 1823, och de voro kringspridda i Slottet. Där den olika storleken och svårigheten att få rum för den stora mängden har man varit nödsakad att placera dem såsom man kunnat. Uppsatsen är derigenom icke blifven så till åskådarnes lättnad vid beseendet, som man hade önskat'. In the discussion of the gallery I have used the 1830 guidebook, but the content of the different guides are very similar

${ }^{6}$ Åke Livstedt, 'De äldre tavel-hängningarnas historia på Gripsholms slot,' in Porträtt porträtt. Studier i Statens porträttsamling på Gripsholm, ed. by U. G. Johnsson, (Stockholm: Rabén \& Sjögren, 1987), p. 25.
} 
It should be underlined, firstly, that the majority of the portraits depict members of the aristocracy. Given that the curator and most of his advisors were also part of this same group, this is hardly surprising. It is also due to the fact that the single most common group of persons were politicians. Fifty-four paintings depict members of the Privy Council and another 20 high ranking officers — field marshals and generals — although these groups are partially overlapping. The group of politicians did not exclusively consist of aristocrats though, there were also a few portraits of representatives of the estate of the peasants, ${ }^{7}$ for example the two speakers of the estate Olof Håkansson (1695-1769) and Per Olson (1630-1692), as well as 11 portraits of bishops and archbishops. Apart from being church leaders, they were also politicians representing the estate of the clergy. Very few portraits depicted persons outside of state service, in fact only nine out of the 133 in the gallery. Of these non-state employed persons two were businessmen, three were authors, and one was Saint Bridget of Sweden (1303-1373). This category also includes all six women present in the gallery. Apart from Saint Bridget, these were the authors Sophia Elisabeth Brenner (16591730) and Hedvig Charlotta Nordenflycht (1718- 1763), Wendela Skytte (1608-1629) and Sophia Rosenhane (1651-1693) (two young noblewomen known for their great learning), and Barbro Stigsdotter (c. 1472-c. 1528) who figures in the legends surrounding Gustav I's (1496-1560) ascension to the throne during the civil wars in early sixteenth-century Sweden. ${ }^{8}$

When the portraits in the gallery and the 'wish-list' advertised in the late 1820s are put together, several themes or narratives emerge. The first and most obvious narrative is royalism. ${ }^{9}$ The incorporation of the gallery into a royal palace that was still in use of course sets it firmly within a regal context. The new royal dynasty, the French-born Bernadottes, needed to be legitimized as the proper inheritors to the throne. Including the new king Charles XIV and his son Crown Prince Oscar (1799-1859) in the long line of royal predecessors exhibited on the walls of the old royal palace effectively linked them to the throne and the history of Sweden as two in a long line of royal figures. To this traditional gallery of royal portraits was added the new gallery of 'merited citizens'. With this addition, the royal narrative of the palace arrangement was strengthened because it gave King Charles XIV the opportunity to pose not only as one among his royal predecessors, but also as

\footnotetext{
7 The swedish parliament was from the 16th century until 1866 made up of four estates (the nobility, the priests, the burghers and the pesants). Each estate was lead by a speaker that was elected among the representatives.

${ }^{8}$ For an overwiew of the political history of 16th century Sweden, see M. Roberts, The Early Vasas: A History of Sweden, 1523-1611 (Cambridge: Cambridge University Press, 1968).

${ }^{9}$ I have written more extensively on the dynastic use of the Gripsholm-gallery and other art museums in Sweden during the first decades of the 19th century in 'Dynastic Histories. Art Museums in the service of Charles XIV,' in Scripts on Kingship. Essays on Bernadotte and Dynastic Formation in an Age of Revolution, ed. by M. Alm \& B.-I. Johansson, (Uppsala: Swedish Science Press, 2008), pp. 79-96
} 
the primus inter pares among the 'merited citizens'. This was especially appropriate since he was elected by the Swedish parliament on the grounds of his deeds as a Napoleonic marshal.

But the royal theme is also visible in the gallery itself. Most of the persons in the gallery had some kind of connection to the court, either by being members of the Privy Council or by having positions at the court. But most of the non-noble and comparatively low-ranking persons in the gallery were also connected to the crown, and these histories are briefly sketched in the guidebooks. An example of this is the above-mentioned Barbro Stigsdotter, who figures in histories of how Gustav I ascended to the throne in the early sixteenth century. Stigsdotter is said to have saved the future king from his Danish pursuers when trying to raise a rebellion against the Danish-Swedish king Christian II. Another example is Casten Rönnow (c. 1630-1691/1692), a priest in Scania, who, during the wars between Sweden and Denmark, supposedly saved the life of King Charles XI (16551697). ${ }^{10}$ These kind of stories can be interpreted as highlighting how the people — the citizens loved their kings and their fatherland, and were prepared to make sacrifices and undertake other patriotic deeds for them.

Another strong theme in the exhibition is that of culture and learning. Several of the portraits depict authors, artists, and scholars. Among them are the previously mentioned authors Nordenflycht and Brenner, but also several others like Lars Johansson Lucidor (1638-1634), Carl Michael Bellman (1740-1795), and Olof von Dalin (1708-1763). The artists are represented by David Klöcker Ehrenstrahl (1628-1698) and Gustaf Lundberg (1695-1786) among others, and the scholars include Olof Rudbeck the elder (1630-1702), Nils Rosén von Rosenstein (1706-1773), Johan Ihre (1707-1780), and Carl Linnaeus (1707-1778).

Connected to this theme of scholarship and culture is noteworthy women. Of the six women represented in the gallery, all but one (Stigsdotter) were known as authors (including Saint Bridget) or as women of learning. On the wish-list published in Post-och Inrikes Tidningar there are three more women, including Catarina Bure (1601-1678), presented as 'the learned', and Catarina Båă (d. 1698/1699) renowned as a genealogist. ${ }^{11}$ As opposed to the eighteenth-century tradition of having

\footnotetext{
10 See for example Handbok for resande till Gripsholms slott where Stigsdotter and Rönnow is presented with their names in the list and a very short explanation. Stigsdotter is said to have 'saved King Gustaf [I] Ericsson' and Rönnow gets a foot note where its explained that he 'saved King Charles XI'. The stories were well known to the public and told in for example schools. Handbok för resande till Gripsholms slott, p. 27, 30.

11 Post- och inrikes tidningar 20 March 1827. I have found no evidence of why the third woman on the list, Hedvig Kyhle, was included. There are a Hedvig Kyhle born in 1641(?) to county governor Hans Kyle and his second wife Catarina von der Lühe, but there are no records of her being known for anything particular. Hans Kyle's first wife was the above mentioned Wendela Skytte though, and a sister of Hedvig, Catarina Kyle, was married to county governor Lars Larsson Eld, later ennobled baron Eldstierna. Lars Eldstierna was in turn brother to Samuel Larsson Eld who was ennobled
} 
galleries of beauties representing women, all women in the Gripsholm gallery, although not numerous, were there on the basis of their merits, much like the men surrounding them.

Finally, there is the theme of historical power conflicts, based on those persons who had been victims of struggles between different pretenders to the throne. Examples include Privy Council members Thure Bjelke (1548-1600), Eric Sparre (1550-1600), and Gustaf Baner (1547-1600) who during the civil war between King Sigismund of Poland and Sweden (1566-1632) and Duke Charles (1550 - 1611) (later King Charles IX) in the last years of the sixteenth century were condemned to death by Duke Charles for treason. ${ }^{12}$ In the guidebook their entries are all marked with crosses and the year of their deaths, indicating there is something special about them.

To this group of portraits, though, are also added a series of eighteenth-century portraits that might have been more politically dubious in the 1820s. After the disastrous Russo-Swedish war of 1741-1743 the leading group in the Swedish parliament (known as the Hat's party) sacrificed two of its leaders to retain power. ${ }^{13}$ The generals and politicians Charles Emil Lewenhaupt and Henrik Magnus von Buddenbrock were singled out as scapegoats and executed in $1743 .{ }^{14}$ There was no portrait of Buddenbrock in the gallery, ${ }^{15}$ but a portrait of Lewenhaupt was marked with a cross in the guidebook. The same marking was used for the portrait of Eric Brahe who, as one of the leaders of the court party of the parliament, was executed in 1756 for his involvement in a failed royalist coup de état. These portraits, together with that of Brahe's exiled companion Johan Ludvig Hård af Segerstad and that of major Malcolm Sinclair — whose murder by Russian agents on a diplomatic mission in 1739 was one of the reasons for the 1741-1743 war — are signs of a politicized narrative whereby Stjerneld attempted to rehabilitate both the commander of the Russian war and the coup plotters of 1756. By marking them the same way as the victims of Charles IX's abusive execution of leading noblemen in 1600, Stjerneld suggested that the more recent political trials were unwarranted as well. There are several reasons why he might wish to rehabilitate Brahe and Lewenhaupt. One reason might be that Stjerneld's own political opinions were royalist and therefore in support of the royalist Brahe; another might be the influence of Stjerneld's father's participation in both the political pre-history of the 1741-1743 war and the failed coup de état in 1756.

Stierneld and was the great grandfather of Adolf Ludvig Stjerneld which means that there might be a family tradition about Hedvig Kyle.

12 See Roberts, The Early Vasas, pp. 327-393.

${ }^{13}$ For an overwiew of Swedish politics during the parliamentary rule of the 18th century, see M. Roberts, The age of liberty. Sweden 1719-1772 (Cambridge: Cambridge University Press, 1986).

${ }^{14}$ Roberts, The age of liberty, p. 105.

15 Post-och Inrikes Tidningar, see e.g. 15 March 1826, 20 March 1827. 
Although the grand narrative of the gallery revolves around royalty and the relation between the citizens and their kings, that royalism is complicated by a sub- theme showing the crown and the king harm citizens. Thus, the relationship that is presented is between citizen and king, as opposed to subject and king. As such, it reflects the new liberal constitution of 1809 , where the monarch was bound by the constitution as opposed to the greater degree of absolutism enjoyed by Swedish monarchs between 1789 and 1809 .

The nationalistic, patriotic meaning of the gallery is limited, however. As previous research has pointed out, like other national monuments - pantheons, museums, etc. - that often used an inclusive language which spoke of nation and patriotism, it is far from clear that the gallery actually promoted an emancipatory nationalist agenda. Rather, like comparable institutions, it more often than not offered a 'political discourse intended to preserve an elite's power, consolidate its reputation, and control its legacy'.16

\section{Visitors to Gripsholm}

Despite its rather isolated location in a small town some $70 \mathrm{~km}$ from the capital, the palace and the gallery attracted substantial numbers of visitors. Already in the first years of steamboat traffic in Sweden there were regular tours between Stockholm and Gripsholm, a tour that in the 1830s became so popular that several shipping companies competed for the tourists.

Admission to the palace was free and there was a custodian (slottsvaktmästare) employed to take care of the visitors, answer their questions, and sell guidebooks. ${ }^{17}$ The number of visitors to the gallery and the palace is difficult to assess, but by comparing the visitors' log from the palace with a diary entry by Stjerneld, we can get a sense of its popularity. The visitors' log opens with an entry from 10 October 1823 when King Charles XIV visited the palace in the company of Queen Desire e, the Crown Prince Oscar and his newly wedded wife Crown Princess Josephine of Leuchtenberg, and a large entourage. ${ }^{18}$ There follows a long list of names of nobles and leading bourgeois.

The overall visitor numbers recorded in the log are comparatively small, especially during the first years, but in a diary entry for Midsummer's Day 1833 Stjerneld noted that 450 visitors attended

\footnotetext{
${ }^{16}$ E. G. Bouwers, Public Pantheons in Revolutionary Europe. Comparing Cultures of Remembrance, c. $179+-1840$ (Basingstoke: Palgrave MacMillan, 2012), pp. 5-11. See also L. Völker, Tempel für die Großen der Nation. Das kollektive Nationaldenkmal in Deutschland, Frankreich und Großbritannien im 18. Und 19. Jabrbundert (Frankfurt am Main: P. Lang, 2000).

17 Although the foreword of the 1826 guide Bihang till Gripsholms slotts beskrifning af ar 1826 [a supplement to the guide published the previous year] hints that the custodian not always did his job properly since it clearly states what his duties were and what the visitor could expect from him.

18 Gästbok 1823-1856, Gripsholms slott.
} 
that day, coming from the surrounding countryside as well as on steamships from Stockholm. By comparison, the visitor log records only 64 names. ${ }^{19}$ The difference between the two numbers shows that relatively few visitors signed the log and the actual number of visitors to the palace must have been much higher. From other palaces and from the Kungl Museum, located in the royal palace in Stockholm, we also know that people from all classes visited palaces and museums, from farmhands and milk maids to members of the aristocracy. ${ }^{20}$

Despite the gallery's aristocratic focus and originators, it is clear that it succeeded in attracting the public's interest. The palace continued to attract interest during the nineteenth century, shown by a steady flow of new guidebooks, paintings, and lithographs with motifs from Gripsholm. ${ }^{21}$

\section{The national portrait gallery explained - guidebooks and contexts}

The Gripsholm palace began as a sixteenth-century fortified castle that was subsequently used as a summer residence by the court. After being more or less uninhabited during most of the eighteenth century, Gripsholm was restored to use by Gustav III (1746-1792) who appreciated its association with medieval knights, their deeds, and their valorization during the Romantic era. The historical connections between the palace and its commissioner - Gustav I, often perceived as a 'father of the nation' - were also used by Gustav III in his propaganda.

As opposed to other museums where palaces were used as exhibition halls, like the Louvre and the Versaille in France, the Christiansborg Palace in Denmark, the Mauritshuis in the Netherlands, or the Belvedere in Austria, the palace rooms of Gripsholm were not rearranged in any substantial way to accommodate royal and other portraits. ${ }^{22}$ And as opposed to the aforementioned examples, the palace was not taken out of royal use, but rather continued as a royal residence after the National Portrait Gallery opened. The use of a historic or historicizing setting for the gallery is not unknown during the period, though, but recalls other museum interiors like the well-known Muse'e des

\footnotetext{
${ }^{19}$ Diary entry 24 June 1833, Uppsala university library X 299e. Gästbok 1823-1856, Gripsholms slott.

${ }^{20}$ P. Widén, Från Kungligt galleri till nationellt museum. Aktörer, praktik och argument i svensk konstmuseal diskurs ca 1814-1845 (Göteborg/Hedemora: Gidlunds förlag, 2009), pp. 114-121, 214-215.

21 The best known example of this is the series of lithographs published 1853-1855 by Carl Johan Billmark (printed in Paris by Lemercier) under the heading Gripsholm with romantisiced exteriors and interiors populated by historical actors like Gustavus Adolphus and Erik XIV

22 On the arrangements of the Louvre, see e.g. A. McClellan, Inventing the Louvre. Art, Politics and the Origins of the Modern Museum in Eighteenth Century Paris (Berkeley \& London: University of California Press, 1994). On Versailles, see e.g. T. W. Gaehtgens, 'The Historical Museum at Versailles' in Rethinking France. Les Lieux de Memoire 4, ed. by P. Nora, (Chicago \& London: University of Chicago Press, 2010). On the Christiansborg gallery, see V. Villadsen, Statens Museum for Kunst 1827-1952 (København: Gylendal, 1998). On the Mauritshuis, see H. E. Hoetink, ed., Gezicht op bet Mauritshuis. Poëtische visies op een nitzonderlijk museum (Amsterdam: Meulenhoff, 1989), on the Belvedere, see D. J. Meijers, Kunst als natuur. De Habsburger schilderijengalirij in Wenomstreeks 1780 (Amsterdam SUA, 1991).
} 
Monuments de Franc ais in Paris. ${ }^{23}$ As opposed to it, the portrait gallery at Gripsholm made use of its authentic historical environment, a fact emphasized in gallery guide books and presumably by the palace guides when escorting visitors.

From 1825 onward a number of palace guides were published, all written by Stjerneld for a wider audience. ${ }^{24}$ The palace guides were all printed in small formats and clearly written, easy to bring to the palace or to be sold on site for visitors' self-guided tours. Most of them contained a foreword that explained the palace history and its place in the history of Sweden, as well as stories about famous and important persons associated with the palace. The rest of the books' contents consists of lists of paintings, their locations, and brief descriptions of depicted persons' accomplishments. In some cases, the books included room-by- room descriptions of the palace in the manner of modern guide books.

These guides reveal a particularly important facet of this gallery's history and narrative. Stjerneld, in his guidebooks, makes use of the text, the portraits, and the palace interiors to enliven the reader's/visitor's experience. With anecdotes, contemporary and more or less well-known poetry, and pointers towards certain elements in rooms, he appeals to readers' romantic, nationalistic passions. On the title page of several of the guides, Stjerneld makes use of quotations that set the mood and point readers in the 'right', patriotic, direction. The first guide, from 1825, opens up with the words 'Läs häfderne, gör rätt åt fädernas bedrifter' ('read the annals, honour the deeds of your forefathers') a quotation from the poem Skaldebref till dem, som söka ett odödligt namn (roughly translated as 'Poetic letter to those, who seek an immortal name', or 'immortal glory') by the member of the Swedish Academy, Isac Reinhold Blom (1762- 1826). ${ }^{25}$ The tone of the quotation is urgent, reminding the reader of a duty to fulfil and quite possibly inspiring pride. Another of the guides begins with the lines:

\footnotetext{
23 On the Musée des monuments de Français, see e.g. J. Carter, 'Recreating Time, History, and the Poetic Imaginary: Alexandre Lenoir and the Musée des Monuments français (1795-1816)' (PhD diss., McGill University, 2007); D. Poulot, 'Alexandre Lenoir and the Museum of French Monuments' in Rethinking France, ed. by Nora; McClellan, Inventing the Louvre, pp. 155-197.

24 These are: Adolf Ludvig Stjerneld, Gripsholms slott (Stockholm 1825); Bihang till Gripsholms slotts beskrifning af år 1825 (Stockholm 1826); Korrt uppsats på det anmärkningsvärdaste som sedan sommaren år 1822 kommit till Gripsholms slott (Stockhlom 1827); Handbok, for resande till Gripsholms slott (Stockholm 1830, translated into French in 1836 and to German 1842); Gripsholms-galleriet (Stockholm 1833).

25 Stjerneld, Gripsholms slott, title page. My translation. Blom's poem was published in 1792 and rewarded with the Grand Prize of the Swedish Academy the same year.
} 
Gripsholm is not only the old Royal Knight's Castle [...] Here, surrounded by the proud and the bad individuals of History, the thinking person's deepest reflections can be made, with the eye gazing on images of the renowned or the notorious. ${ }^{26}$

The aim of the gallery is quite clear. The marvellous line of persons depicted in the gallery should serve as a national and patriotic example of the classical 'Historia magistra vitae' where the visitor, regardless of rank, could (or should) see and learn. A similar purpose was expressed when, some 30 years later, the British National Portrait Gallery was founded. ${ }^{27}$ The 1833 guide Gripsholms-galleriet stated:

The Swede can proudly know that Sweden owns more exceptional men, from the sceptre to the plough, than any of the most brilliant countries, when the number of inhabitants is taken into account. ${ }^{28}$

To further heighten the mood, Stjerneld drew on notions about the Middle Ages familiar from romantic novels by authors like Sir Walter Scott to describe what might have happened on the castle grounds. ${ }^{29}$ When presenting the reader with a portrait of Gustav I in the audience chamber, Stjerneld quotes the immensely popular and nationalistic opera 'Gustaf Wasa', by Johann Gottlieb Naumann (with libretto by Johan Henrik Kellgren and King Gustav III), to underline the high moral standard of the king and the sacrifices made by Gustav I in his struggles to free Sweden from Denmark during the civil wars around 1520. The description of the same room also tells the romantic story of a concealed staircase as well as a hidden barrel of gold, both motifs well known from contemporary novels. ${ }^{30}$ When describing the contents of the palace armoury, Stjerneld conjures the same kind of chivalrous feelings, telling the reader/visitor that

here are also weapons after our Kings, and several armours, some of them with bullet holes and bloodied, being witnesses to their boldness; maybe, some rusty armour after brothers in arms, who earlier in this very castle have saluted each other; there could also be weapons here,

\footnotetext{
26 Stjerneld, Bihang till Gripsholms slotts beskrifning. My translation, original quote: 'Gripsholm är icke endast det gamla Kongliga Riddare-Slottet, [...] der, omgifven af Historiens stolta eller dåliga individer, kan den tänkandes djupaste betraktelser göras med ögat fästadt på ryktbarhetens eller onyttans afbilder'.

${ }^{27}$ M. Pointon, Hanging the Head. Portraiture and Social Formation in Eighteenth-century England (New Haven \& London: Yale University Press, 1993), pp. 227-245.

28 Stjerneld, Gripsholms-galleriet, title page.

${ }^{29}$ E.g. in Stjerneld, Gripsholms slott, p. 41f, 48, 51, 53.

30 Stjerneld, Gripsholms slott, pp. 51ff. For the same reason, he also picks up motifs from old ballads and folk songs that were collected, published and spread to a wide middle- and upper class audience during the 1810s and 1820s.
} 
that have been used by glorious knights in tournaments, carrying the picture of their loved one in their heart, and with the saying upon their shields: God, King and Fatherland. ${ }^{31}$

This use of poetry and romantic imagery to make history comprehensible was not uncommon during the Romantic period, as was evident in the work of German and Swedish authors, philosophers, and historians like Friedrich Schlegel, Friedrich Wilhelm Schelling, Novalis, Per Daniel Amadeus Atterbom, Erik Gustaf Geijer, Adolf Törneros, and Carl Jonas Love Almqvist. For example, in Vorlesungen über die Methode des akademischen Studiums (1803) Schelling claimed that history writing could not be scientific if it was at the same time also art. History depends on art to fulfil its proper role. ${ }^{32}$ The professor of Latin (and later aesthetics) Adolf Törneros went so far as to claim that Walter Scott was a model for the historians. In a review of Scott's novel Quentin Durward (1823), Törneros argued that many historical periods could be dramatized without sacrificing historical accuracy. The fictional hero in Scott's novel, Törneros argues, plays a small part in a true historical drama. ${ }^{33}$ Törneros's view was not unique and was in line with many influential philosophers and historians of the period. Where history and historians always risked getting stuck in details, poets and novelists could focus on the essence of an era, and thereby present a story that was almost truer than history itself. ${ }^{34}$

In the guidebooks Stjerneld also made numerous claims of authenticity; he connects the stories he is telling to written documentation, he claims to have read certain documents, and tells the reader where to find them if they wish to check the sources. In telling the reader/visitor about the size of the estate during the reign of Gustav I, he quotes specified documents in the National Archives, and when describing the rooms where Duke Johan (III) was imprisoned he cites source documents published by a history academy that Stjerneld had been helping create. ${ }^{35}$ Sometimes he is more vague, however, as when he wrote about a 14-day- long banquet held by Gustav I but cited 'several printed documents' that were unspecified. ${ }^{36}$

The centrality of authenticity is also apparent in Stjerneld's argument about the originality and dates of paintings and other objects. ${ }^{37}$ In an explanatory footnote to the first described room of the

\footnotetext{
31 Stjerneld, Gripsholms slott, pp. 34.

32 U. Josefsson, 'Det romantiska tidehvarfvet'. De svenska romantikernas medeltidsuppfattning (Uppsala: University of Uppsala, 2002), p. $88 f$.

33 Josefsson, p. 99.

34 Josefsson, pp. $104 \mathrm{f}$.

35 Stjerneld, Handbok för resande till Gripsholms slott, pp. 7, 123.

36 Stjerneld, Gripsholms slott, p. 9.

37 See e.g. Stjerneld, Handbok för resande till Gripsholms slott, p. 27 ('original by Merian' about a portrait of Axel Oxenstierna).
} 
1825 guide book, he explains that portraits of Swedish persons living before 'the age of Gustaf I' (before c. 1520) lack credibility if they are not copies of medieval wall paintings or tapestries. ${ }^{38}$ Later in the text he criticizes a portrait of 'An unknown knight' by discussing historical contradictions among the subject's garments, beard, and an inscription that has been discovered since the portrait's arrival at Gripsholm. This kind of probing analysis served to make Stjerneld's claims to authenticity more trustworthy. ${ }^{39}$

This claim for authenticity is paired with a narrative subtext: the persons depicted in the portraits, the faces being observed and that are looking back at the visitor, have, or at least might have, been walking through the same rooms as the visitors. They are, claims Stjerneld, actually standing IN history and experiencing the same things as the exciting and important persons he or she is reading about and seeing in the portraits. When telling the story of King Sigismund's birth during his parents' Duke Johan (III) and Katarina Jagellonica's captivity in the palace, Stjerneld stresses that the visitor is in the actual room and observing the actual bed where this happened. ${ }^{40}$

\section{Curating in a historical environment}

That the connection between room, portrait, and history is not used to a larger degree is not as strange as it might seem. The idea of the period room was not invented in 1823, when Gripsholm opened, and the stylistic furnishings of palace rooms were mixed. It would be another 70 years before the idea that each room should be true to one period and not blend furniture and wall coverings from different periods would be pursued at Gripsholm and other royal palaces. ${ }^{41}$ The connections between history, palace interiors, and portrayed persons are made explicit in the forewords of guidebooks. ${ }^{42}$

\footnotetext{
38 Stjerneld, Gripsholms slott, p. 18.

39 That this discussion really was necessary is shown by the fact that the authenticity of many of the portraits have been questioned during the 20th century, not least the ones acquired by Stjerneld who is also known to have worked as forger of historical documents. See P. Widén, 'Adolf Ludvig Stierneld'.

40 Stjerneld, Gripsholms slott, p. 117f. The story is made even more vivid by the fact that Stjerneld also lists the names of the persons that guarded the ducal couple, as well as telling a romanticised story of how Katarina Jagellonica chose to join her husband in captivity, rather than spend her days alone in a more comfortable setting.

$41 \mathrm{On}$ the question of style and the renovation of Gripsholm slott, see L. Ljungström, Aendnu gamblare: Fredrik Lilljekvists restaurering av Gripsholms slott och 1890-talets restaureringsdebatt (Nyköping: Södermanlands museum, 1987).

42 In the short introduction to the palace and the gallery, Gripsholms-galleriet from 1833, the reader/visitor was told about the aforementioned banquet of Gustav I in 1544, about how Gustavus (II) Adolphus in the Hall of State knighted the young Lennart Torstensson (later to become one of the most well known generals of the 30 Years War), and about the merry visits by the court of Gustav III. The same stories are, with some variations, retold in the other guides. The 1825 guide in particular has a very long historic introduction that introduces the reader/visitor to the palace and its historical actors. Stjerneld, Gripsholms-galleriet, p 18ff ; Stjerneld, Gripsholms slott, pp. 1-17.
} 
The inspiration for the museum's use of historic spaces certainly came from many places, and different parts of the museum are in many cases recognizable from other contemporary European museums like the above mentioned Musée des Monuments de Français. ${ }^{43}$ But two main sources of inspiration can be traced: first, to the legacy of Gustav III and his interest in theatre, opera, and what could be called live role playing; and second, the masonic order and its interest in ritual and ritual spaces. Gustav, who reigned from 1772 until he was murdered (at a masquerade ball) in 1792, had a keen interest in opera and theatre both for the aesthetical and political possibilities of the medium. He wrote and co-wrote several plays and opera librettos, mostly with historical themes. Most famous among them is the above mentioned opera 'Gustaf Wasa', the first opera written in the Swedish language, and set during the civil wars of the 1520s when Gustav I 'liberated' Sweden from its union with Denmark.

The court of Gustav III, where Stjerneld acted as a young chamberlain to the queen, was also a centre for the Swedish version of the German 'Sturm und Drang' movement and an early craze for the Middle Ages and knightly deeds and values. This interest in the Middle Ages grew beyond novels and court theatre, into huge, live public re-enactments with tournaments, knightly battles against faux dragons, and rescues of kidnapped ladies. During the 1770s and 1780s the king hosted a number of such spectacles. ${ }^{44}$ During the tournaments the king and his court, who participated as actors, dressed up in Burgundian Renaissance garb and historical armour. Most of the props were made especially for the occasions, but some costumes were authentic seventeenth century garments collected from the royal wardrobe. ${ }^{45}$

Another source of inspiration, which is actually linked to the carousels, might have been the masonic order. Other scholars observed the masonic inspiration in several museums from the early nineteenth century. It has been pointed out that both the Soane museum in London and the Musée des monuments de Français in Paris were influenced by masonic ideas, and may have also been used as settings for masonic rites. ${ }^{46}$ The Soane museum is unlikely to have been an inspiration to Stjerneld because it was too obscure and was created too late for that. But there are several similarities

\footnotetext{
43 It is unclear wether Stjerneld visited the Musée des Monuments de Français, there are indications on that he visited Paris in 1801. It is certain though, that he owned a copy of one of the descriptions of the museum, the 1810 Musée Imperial des Monument Francais by Alexandre Lenoir as well as several other museum descriptions and guides like the Catalogue des Tableux de La Galerie de Vienne by Christian von Mechel. His library catalogue reveals a thorough interest in museums. Uppsala university library, Bibliotekets arkiv, K 80a.

${ }^{44}$ M. Olausson, 'Tournaments and carousels in the Gustavian era,' in Gustavian Opera: an Interdisciplinary Reader in Swedish Opera, Dance and Theatre 1771-1809, ed. by I. Mattsson, (Stockholm: Royal Swedish Academy of Music, 1991).

45 Olausson, p. 225

46 D. Preziosi, Brain of the Earth's Body. Art, Museums, and the Phantasms of Mordernity (Minneapolis: University of Minnesota Press, 2003), pp. 63-91; Carter, pp. 95-169.
} 
between Gripsholm and the Musée des Monuments de Français. The Canadian art historian Jennifer Carter has shown that the scenographic and curatorial practices performed by Alexandre Lenoir at the Musée des Monuments de Français most likely was influenced by Lenoir's experiences as a freemason, especially in his use of light, allegory, and iconography in the interiors and in creating a pathway through the exhibitions that made passages through them seem like ritual enactments. ${ }^{47}$ The entire museum was structured as a journey from darkness to light and from past to present, easily interpreted as a procession towards enlightenment. This journey from dark to enlightenment is also a major theme in masonic rituals, and the designs of at least some of the Muse e des Monuments de Franc ais halls were modelled on masonic lodge rooms. ${ }^{48}$

The possible masonic influences on the national portrait gallery of Gripsholm are less obvious, but not improbable given Stjerneld's membership in the Grand Council of the Swedish Order of Freemasons and participation in rewriting the Swedish Rite during the decades around $1800 .{ }^{49}$ The connection here has less to do with the settings of objects and the designs of rooms, than with the use of space in the museum, and how Stjerneld combined poetry, facts, and space in the museum. When creating the Gripsholm gallery, Stjerneld had to adapt his exhibitions to the existing historical environment and could not freely create an independent setting. Instead, any likeness to masonic rites lay in the gallery's pedagogical structure. The masonic ritual is organized around narrative roleplaying, intended to enact a comprehensive educational experience for the person to be initiated. The ritual makes use of poetry and verse, as well as movement through rooms, making use of the space to put the initiate in a certain mood so as to render the experience as effective and educational as possible, the interpretation of which is guided by the head of the ceremony.

For Gripsholm gallery visitors, the guide books served as ceremonial heads, tracing the route throughout the palace and museum, and setting the mood through the use of poetry and historical anecdotes; the texts highlight noteworthy objects and how they are to be interpreted, and literary sources are used to set a mood and enhance the narrative. Thus, Stjerneld's guidebooks can be read, like Carol Duncan's interpretation of the Louvre's interior architectural programme, as 'civilizing rituals' - in this instance, the ritual serving the ends of Swedish patriotism. ${ }^{50} \mathrm{I}$ would argue, though, that the arrangements at Gripsholm and the guidebooks that accompany them, make the

47 Carter, pp. $120 \mathrm{f}$.

48 Carter, pp. $159 \mathrm{f}$.

49 Widén, 'Adolf Ludvig Stierneld'.

${ }^{50}$ C. Duncan, Civilizing Rituals. Inside public art museums (New York: Routledge, 1995), pp. 7-20. 
combination of both a more powerful example of the influences of masonic rites and the uses of ritual-performance in heritage sites. ${ }^{51}$

\section{Conclusion}

In the period between the early museum projects of the late eighteenth century and the expansion and scientification of the world of museums of the middle of the nineteenth century, the National Portrait Gallery of Sweden was created. While building on the traditional royal picture gallery, the National Portrait Gallery also included what was spoken of as 'meritorious citizens', which was supposed to inspire and create national feelings in the visitors. The narrative of the gallery was told not only by the portraits, but was also making use of the historical palace interiors and of guide books that tried to create a mood in the visitor with the help of romanticized anecdotes, poetry, and quotes from plays, novels, and operas. The location of the gallery in a royal palace meant that the narrative was by necessity royal, but an analysis of the guidebooks written by its curator, Adolf Ludvig Stjerneld, shows that it also in subtle ways negotiated the relation between citizen and monarch. Like many other national monuments and museums of its time, the gallery was created by aristocratic members of the pre-revolutionary elite, which means that its inclusive nationalistic and patriotic message was limited. Despite that, the gallery seems to have attracted large amounts of visitors in its early years, probably due to its inclusion in what was already a well-known heritage site and a popular excursion. The gallery's location in a sixteenth-century royal palace, paired with the apparent lack of predecessors, meant that the new museum became a rather original, but at the same time rather typical, exponent of an early nineteenth-century museum with national ambitions.

\section{Acknowledgement}

This article is part of the author's research project 'Creating a Patriotic History', financed by the Swedish Research Council.

\footnotetext{
51 The ritual interpretation of the gallery is also supported by some passages in the guidebooks. In the 1830 guide, Stjerneld writes about the gallery visit as a 'pilgrimage' and of the gallery as a 'sanctuary of Swedish history' and in the 1825 guide the gallery is called a 'collection for the patriotic feeling'. The donation of portraits to the gallery by 'noble Swedish citizens' is also described as a patriotic deed. Stjerneld, Handbok för resande till Gripsholms slott, p. 3; Gripsholms slott, p. 83.
} 